\title{
Conhecendo Os Paradigmas Catequéticos 1
}

\author{
Understanding CATECHETICAL PARADIgMS
}

\begin{abstract}
Alex Cristiano dos Santos ${ }^{(*)}$ SOLANGE MARIA DO CARMO ${ }^{(*)}$
\end{abstract}

\begin{abstract}
RESUMO
A catequese, especialmente a partir da Reforma Protestante, foi conduzida por paradigmas que emergiram das necessidades de cada tempo. Com o cisma protestante, a fé católica se viu impelida a desenvolver uma catequese capaz de afirmar sua identidade (cristã-católica) frente ao florescimento e crescimento da Igreja protestante. Surge, aqui, a catequese doutrinária, alicerçada nos catecismos (primeiro paradigma). Esta será abalada pelo advento da razão moderna, que traz consigo novas demandas. Frente a essas demandas, emerge um novo paradigma catequético (segundo paradigma) que, buscando responder os anseios do homem moderno, não parte mais da doutrina, mas da concretude existencial dos sujeitos. Todavia, nenhum desses paradigmas, já consolidados, mostra-se suficiente para atender às necessidades da catequese frente às reivindicações do homem contemporâneo. Surge, assim, o terceiro paradigma catequético, ainda em construção, que busca um retorno à pedagogia "original da fé", a pedagogia da iniciação, da proposta, capaz de proporcionar uma experiência pessoal do Ressuscitado, transformando as vidas e as ações dos indivíduos contemporâneos e de suas comunidades.
\end{abstract}

Palavras-Chave: Paradigmas. Cristandade. Modernidade. Pós-modernidade. Catequese.

\section{ABSTRACT}

The catechesis, especially after Protestant Reformation, was conducted by paradigms that emerged from the needs of each age. With the Protestant Schism, the catholic faith had seen itself impelled to develop a catechesis able to assert its identity (Christian-Catholic) compared to the emergence and growth of the Protestant Church. The doctrinal catechesis arises, based in catechisms (first paradigm). This will be shaken by the advent of Modern Philosophy reason, which brings with it new demands. In front of these demands, emerges a new catechetical paradigm (second paradigm) which, seeking to answer the desires of Modern man, no longer starts from the doctrine, but from the existential concreteness of subjects. However, none of these paradigms, already consolidated, seems sufficient to answer the catechesis needs for the demands of contemporary man. Thus arose the third catechetical paradigm, still under construction, which seeks a return to the "original faith" pedagogy, the initiation and proposal pedagogy, able to provide a personal experience of the Risen One, transforming the lives and actions of contemporary individuals and their communities.

KEYWORDS: Paradigms. Christianity. Modernity. Postmodernity. Catechesis.

\section{INTRODUÇÃO}

O processo de secularização da catequese vem acontecendo de longa data. Trento (século XVI) institucionalizou com seu catecismo uma espécie de "ensino religioso" para combater a "ignorância religiosa". Desde a renovação catequética do começo do século XX, esforços têm sido empreendidos na tentativa de

\footnotetext{
1 Artigo resultante do trabalho de pesquisa do aluno de graduação em teologia Alex Cristiano dos Santos, sob a orientação da professora Dra Solange Maria do Carmo, financiado pela FAPEMIG, a quem agradecemos o apoio, e vinculado ao PROBIC da PUC-Minas.

${ }^{(*)}$ Graduado em filosofia pela FAM - Faculdade de Mariana; graduando em Teologia na PUC-Minas, $6^{\circ}$ período.

${ }^{(* *)}$ Professora da PUC-Minas, mestre em teologia bíblica e doutora em teologia catequética pela FAJE Faculdade dos Jesuítas - Belo Horizonte/MG. E-mail:
} 
superar a catequese escolástica, dedutiva, investindo forças não na doutrina, mas no catequizando, sujeito de sua própria catequese. Mas fazer uma catequese mais mistagógica e iniciática e menos escolástica não é tarefa das mais fáceis. Todo esforço da renovação catequética (ou da catequese renovada no Brasil) não foi suficiente para tal. Apesar de todo avanço percebido nesse caminho, resulta uma catequese escolarizada, sempre preocupada com o saber, com as razões da fé, cujos caminhos pedagógicos não coadunam com a "pedagogia original da fé" (DGC, 138)².

O processo de escolarização da catequese tem muito a ver com os paradigmas catequéticos que se firmaram ao longo dos séculos e que, ainda hoje, vigoram na catequese católica. Um paradigma catequético é bem mais que um modelo didático-pedagógico. Paradigmas são linhas epistemológicas que delineiam um modo de pensar e agir, um caminho pelo qual a catequese acontece; ou seja, um norte que define a catequese em todos os sentidos, tanto sua pedagogia, quanto sua teologia, sua eclesiologia etc.

Denis Villepelet, catequeta francês, desenvolveu uma interessante teologia catequética acerca dos paradigmas catequéticos (2007). Neste artigo, iluminados por sua teologia, vamos apresentar os três paradigmas catequéticos que se delinearam na história. Dois deles parecem muito bem definidos e são visibilizados com facilidade: o primeiro é o paradigma da cristandade e o segundo é o paradigma da renovação catequética. O primeiro, buscando responder aos questionamentos da Reforma Protestante, afirmava a identidade cristã-católica, por meio do ensino da doutrina contida nos catecismos. $\mathrm{O}$ segundo, buscando responder aos questionamentos da modernidade (virada antropocêntrica), construiu uma catequese antropológica, transferindo o foco da doutrina e do catequista para o catequizando, cuja capacidade cognitiva foi entendida como construtora do conhecimento de Deus. Os catecismos do primeiro paradigma - que davam a verdade pronta para ser respondida com a obediência da fé - se viram substituídos por catecismos locais, que eram ou elaborações teológicas com pressupostos na razão crítica da modernidade ou manuais catequéticos locais que retratavam a preocupação com a realidade social do catequizando.

O terceiro paradigma - da pós-modernidade - ainda se encontra em vias de construção, mas já é possível esboçá-lo a partir da observação de práticas catequéticas que, pouco a pouco, se implantam nas comunidades eclesiais, angariando a simpatia dos contemporâneos e a rejeição de alguns que têm

${ }^{2}$ Nota do editor: Diretório Geral para a Catequese, 138 ([DGC 138, 2016]). 
dificuldades para lidar com a mudança epocal 3 . Conheçamos os paradigmas, um pouco de sua história e suas características.

\section{PRIMEIRO PARADIGMA: CATEQUESE DA CRISTANDADE}

Após o Edito de Tessalônica (380 dC) em que o Imperador Teodósio declara o cristianismo como religião oficial do Império Romano, a sociedade torna-se marcada pela presença maciça de cristãos, por convicção ou conveniência, pois os que assim não se declarassem poderiam se tornar vítimas de perseguição. A essa sociedade, marcada pela cultura cristã, na qual o poder temporal e o poder espiritual se encontravam atrelados, denomina-se "cristandade". Nesse período, a Igreja possuía hegemonia e ser cristão era ser católico.

Com o advento da Reforma Protestante, a Igreja se viu ameaçada e sentiu-se impelida a emitir uma resposta que pudesse afirmar a sua identidade frente aos questionamentos que lhes foram dirigidos. A Igreja reagiu com o Concílio de Trento (1545-1563), que incumbiu Carlos Borromeu de elaborar um catecismo para o povo. O chamado Catecismo dos Párocos 4 é um compêndio facilitado da doutrina cristã católica, marcando sua identidade frente à Reforma. Do desejo de afirmação da identidade católica através da doutrinação do povo, surge o primeiro paradigma catequético. "Ganha espaço na Igreja uma catequese cujo objetivo se encontra na transmissão da doutrina, por meio de um resumo facilitado, fornecendo ao fiel as ferramentas necessárias para viver sua fé na sua comunidade de pertença” (CARMO, 2012, p. 84).

$\mathrm{O}$ primeiro paradigma catequético orienta-se do conteúdo da fé (a fides quae 5 ) para o modo de vivenciá-la (a fides $q u a^{6}$ ). Os catecismos, simplificação da doutrina cristã católica à qual o povo tem acesso, buscam combater as afirmações luteranas, ao mesmo tempo em que fornecem aos fiéis o instrumental para viver a sua fé como membros de uma comunidade à qual pertencem (VILLEPELET, 2007, p. 127).

No período de cristandade, a sociedade apoia-se na transmissão de um conjunto de valores, símbolos e significados, chamado tradição, acolhida como

\footnotetext{
3 Sobre a mudança epocal e sua troca de valores, consultar: AMADO, 2008, p. 301-317; AMADO, 2010, p. 565-579. Explicação clara sobre a mudança de época aparece também nas Diretrizes Gerais da Ação Evangelizadora, Doc 94 da CNBB (DGAE 2011-2015).

4 A tradução exata de Catechismus ad Parochos é Catecismo para os Párocos, que deveriam assimilá-lo e ensiná-lo ao povo, mas a expressão popular Catecismo dos Párocos já se consagrou.

5 "A fides quae creditur - a fé que se crê - refere-se ao objeto, ao conteúdo da fé. Relaciona-se mais diretamente à Revelação passiva, ao credere Deum" (LIBANIO, 2004, p. 155-156).

6 "A fides qua significa a fé por causa da qual se acolhe a Deus. Exprime o ato de fé. É a fé pela qual me volto a Deus em Cristo pelo Espírito Santo por meio da aceitação do que a Igreja crê (fides quae)" (LIBANIO, 2004, p. 156).
} 
valor inestimável a ser repassado às gerações futuras. Transmitir a tradição é a prioridade dessa sociedade, pois ela lhe confere identidade. Essa é assumida como a própria vida da comunidade, orientando um estilo de vida, ou seja, um modo de viver, de compreender a vida e o mundo, e de se expressar das pessoas. Numa sociedade homogeneamente cristã, a Igreja - enquanto detentora da palavra - assume uma posição hegemônica no meio social. Nessa sociedade tradicional, a fé cristã, em vez de pessoalmente assumida, é herdada como uma característica genética hereditária, advinda dos pais; é uma tradição cultural.

Num ambiente existencial em que se predomina a força da tradição, $o$ indivíduo apresenta-se como parceiro da realidade social na qual está inserido, assim como das instituições à qual pertence. $\mathrm{O}$ sujeito se sente bem com a comunidade e com as instituições que a regem, tornando-se responsável pela transmissão da tradição que faz parte de sua vida. Esse indivíduo cultiva, em si, um espírito de "pertença", tanto com a sociedade, quanto com as instituições, buscando exercer seu carisma para a manutenção dessas e para o bem geral do grupo ao qual pertence.

A Igreja da Cristandade é concebida como Corpo de Cristo, uma sociedade perfeita, estável, organizada e hierárquica, detentora da verdade e responsável pela sua transmissão. A Igreja busca, por meio de sua doutrina, anunciar a verdade para que todos a assumam e nela permaneçam. Assim, a palavra da Igreja-instituição assume e exerce poder de autoridade, dominando e difundindo as normas morais regulamentadoras do convívio social.

Nesse contexto de cristandade, prevalece uma teologia teoderivada: entende-se que tudo provém de Deus, que revela a verdade, fundamento de todas as coisas. Somente Cristo fala em nome de Deus e, consequentemente, a Igreja, instituída por ele como continuadora de sua missão. A pergunta primordial de todo indivíduo é sobre Deus, sendo que sua resposta pode ser compreendida de duas formas: como objetiva e clara (tudo é desígnio ou vontade de Deus) ou como "mistério de Deus" (que deve ser aceito ainda que não entendido). A missão da catequese enquanto transmissora de doutrinas não é primeiramente fazer com que o catequizando elabore seu conhecimento de Deus, mas ajudá-lo a dar sua resposta obediente a partir do que lhe foi ensinado. O que foi ensinado deve ser escutado, assimilado, apreendido, guardado de cor, obedecido.

"Para este paradigma, o aspecto didático é predominante. A mediação racional é necessária ao desenvolvimento da inteligência da fé. Privilegia-se uma pedagogia de ensino com todas as formas de atividades que ela desenvolve" (VILLEPELET, 2007, p. 131). O foco da pedagogia do ensino encontra-se sobre 
aquele que ensina (o catequista) e sobre o conteúdo que é ensinado (os catecismos). O catequizando é concebido como um "cérebro vazio", uma "tábula rasa” na qual, pela exposição, a catequese infundirá uma doutrina a ser assimilada e obedecida. Parte-se do pressuposto que as perguntas do catequista e dos catequizandos são as mesmas e que essas são, adequadamente, respondidas pela doutrina contida nos catecismos. $\mathrm{O}$ trabalho catequético, ao longo do tempo, diminui a ignorância do catequizando, tornando-o responsável por viver e anunciar a doutrina que lhe fora transmitida.

Decorar o catecismo, guardá-lo de cor, era uma tarefa do catequizando, que demonstrava pela pronta e exata resposta sua disposição cristã. Essa preocupação com o saber a doutrina cresceu e se firmou mais tarde, tornandose inclusive uma preocupação marcante de alguns papas. Como afirma Molinario, "a aprendizagem mnemônica do texto do catecismo demandou uma grande preocupação papal desde Pio X até Pio XII [...]. O catecismo observemos - foi concebido para uma sociedade em regime de cristandade" (2006, p. 28). Numa sociedade marcada pela maioria absoluta de cristãos e pela força da Igreja no meio social, a catequese doutrinal conseguiu alcançar o objetivo de consolidar a identidade cristã-católica frente às contestações da Reforma Protestante. Todavia, com a chegada da modernidade, a sociedade tradicional entrou em decadência e uma sociedade com bases na razão se impôs fazendo com que o paradigma da cristandade não mais respondesse às demandas dos tempos modernos. Surgiu a renovação catequética, tentando construir um novo paradigma em conformidade com as necessidades da modernidade.

\section{SEGUNDO PARADIGMA: CATEQUESE DA MODERNIDADE}

A modernidade chegou desbancando a sociedade tradicional e, com ela, tudo que nela se apoiava. Não demorou para que a catequese tradicional conhecesse seu declínio. A pedagogia do ensino caducara com as novidades pedagógicas e psicológicas que se implantaram. Um tempo novo começou a surgir: a modernidade. Uma nova sociedade se implantou: uma sociedade evolutiva, cujas bases são as promessas da razão:

As novas gerações já não pensam mais como os indivíduos da cristandade. Seu mundo já não gira mais em torno de Deus, das verdades eternas e do sentido da vida. O passado com suas tradições perde campo para o futuro promissor que se abre com tantas descobertas do progresso e da ciência, traduzidas em novidades tecnológicas. O eixo que faz rodar o mundo não se assenta mais sobre a 
transcendência, mas sobre as luzes da razão e suas possibilidades. Deus foi destronado e a razão coroada como rainha-mãe. Fez-se urgente um novo paradigma catequético harmonizado com a nova sociedade que se instalou, com a visão do homem e de Deus que se impôs, com o novo jeito de ser Igreja que despontou no horizonte eclesiológico, com as promissoras descobertas pedagógicas que avançaram no mundo educacional. (CARMO, 2016, p. 79-80).

Uma nova sociedade emergente, com novos sujeitos e novas demandas, exigiu que o processo catequético de transmissão da fé fosse transformado, adequando-se às necessidades de outra realidade existencial. Os avanços do mundo moderno incentivaram a Igreja a buscar outros caminhos dantes desconhecidos para a transmissão da fé, mais adequados ao sujeito e à sociedade que o compõe. As respostas da cristandade anunciadas através de uma catequese doutrinária, que, focando nos catecismos e no catequista, oblitera o indivíduo, já não eram suficientes frente aos questionamentos de uma sociedade e de um sujeito marcados pela forte influência do advento da razão. Fez-se necessária a construção de um novo paradigma mais adequado a tal realidade.

A orientação do segundo paradigma catequético, ou seja, o caminho catequético que ele propõe, parte do modo de viver a fé (a fides qua) para o conteúdo da fé (a fides quae), ou ainda, de uma fé infantil (fides qua infantil) para uma fé adulta (fides qua madura) pela apropriação do conteúdo da fé (a fides quae). O grande responsável por essa mudança de paradigma foi o movimento conhecido como "renovação catequética", que transferiu o foco da catequese do catecismo e do catequista para o catequizando em seu contexto existencial (VILLEPELET, 2007, p. 131). Nessa perspectiva, os catecismos foram substituídos pelos manuais catequéticos locais, elaborados a partir de realidades existenciais que tocam os próprios catequizandos. "Esse paradigma leva em conta a pessoa e seu proceder, o desenvolvimento de sua fé como atitude" (VILLEPELET, 2007, p. 138). O catequizando, antes tábula rasa, passou a ser entendido como agente de sua própria catequese, construtor de seu conhecimento.

Essa mudança de caminho catequético coaduna-se com o tipo de sociedade que se formou: uma sociedade evolutiva, voltada para o futuro, que acontece pelo labor do próprio homem e não mais por um desígnio divino. Nessa sociedade, o moderno rompe com as tradições do passado, buscando construir um futuro a partir da racionalidade criativa e criadora. Trata-se de uma sociedade em busca de emancipação, libertação, que vê suas esperanças de futuro alicerçadas na razão. Acredita-se que a racionalidade, por meio do 
progresso, da técnica e da ciência, conduzirá a humanidade a um futuro melhor. "Nesse paradigma catequético, a Igreja é entendida como uma comunidade evolutiva, uma sociedade que progride e para isso exige a mobilização de todos os atores em torno do mesmo objetivo." (CARMO, 2016, p. 93).

Nesse paradigma, a adesão à fé do indivíduo não advém da herança a ele imputada, mas de uma decisão pessoal, consciente e livre. Por causa de sua fé, $o$ indivíduo assume também a condição de agente sociotransformador, sempre em prol da construção do reino de Deus. O cristão não é mais entendido como sujeito passivo, mas como ator engajado na missão evangelizadora de toda a Igreja. O cristão moderno passa a ser protagonista do próprio futuro, renunciando, sacrificando, doando a própria vida em prol da construção de algo maior. Ser cristão é ser "revolucionário", "militante", lutando por melhores condições de vida para si e para a comunidade.

A teologia, outrora teoderivada, torna-se cristoderivada. Se, no primeiro paradigma, o Pai se revela por meio do Filho; no segundo, Jesus de Nazaré revela os desígnios do Pai. De uma teologia dedutiva, descendente (do Pai para o Filho), passa-se a uma teologia indutiva, ascendente (do Filho para o Pai). O segundo paradigma valoriza sobremaneira o mistério da encarnação do Verbo, sua presença na história da humanidade, sua realidade histórica. Jesus de Nazaré, o homem da Galileia, mostra quem é Deus. O Cristo histórico - a Palavra que se fez carne - é o ponto de partida da teologia. Esse mistério da encarnação traz novo sentido a tudo que é histórico. A realidade existencial na qual o homem encontra-se inserido torna-se, então, o conteúdo da catequese. A proposta salvífica de Deus não é mais uma verdade dogmática, pronta e acabada, mas mensagem a ser hermeneuticamente compreendida a partir da realidade. A resposta do crente é construída a partir de sua realidade existencial, de sua história. Ao homem moderno, é salutar alcançar as "razões" de sua fé, que são construídas a partir de seu processo cognitivo, na limitação de sua história. Assim, sua resposta a Deus também não é uma obediência a verdades acabadas, mas um modo de viver como agente transformador das realidades humanas.

A eclesiologia desse paradigma sustenta-se sobre a imagem de Igreja povo de Deus, povo militante, engajado em causas sociais, comprometido com o desenvolvimento histórico da humanidade. Pelo batismo, a todos é concedido o sacerdócio comum dos fiéis. Isso não os torna presbíteros, mas os faz agentes ativos na missão evangelizadora da Igreja. A ação litúrgica e a missão não são propriedades exclusivas do clero, mas responsabilidade de todo batizado. A 
Igreja não é mais compreendida como instituição hierárquica, mas como comunidade de irmãos, povo de Deus, com missão e objetivos em comum.

A pedagogia desse paradigma é dita como pedagogia da aprendizagem: assenta-se sobre a construção do conhecimento feita pelo próprio catequizando. Ele não recebe passivamente a doutrina que lhe é ensinada, mas elabora seu conhecimento a partir da sua realidade cognitiva e social, a partir do seu mundo, de suas habilidades e possibilidades. A experiência humana se torna chave de leitura para a experiência de fé. O foco não mais se encontra no que é ensinado (catecismos) ou em quem ensina (catequista), mas naquele que constrói seu conhecimento (catequizando), na sua realidade. Ao catequizando cabe, nesse paradigma, não mais decorar ou apreender a doutrina, mas fazer uma leitura da ação de Deus na história, do Deus revelado em Jesus de Nazaré. Por causa dessa leitura da vida, os catecismos são substituídos por diversos manuais catequéticos que trazem dicas para a catequese em conformidade com a realidade do catequizando. Constrói-se uma relação fundamental entre fé e vida. $\mathrm{O}$ ato de crer (a fides qua) torna-se ponto de partida para o ato catequético que deseja chegar às razões da fé (a fides quae entendida como mensagem e não como conjunto de doutrinas).

\section{TERCEIRO PARADIGMA: CATEQUESE NUM MUNDO DESCRISTIANIZADO}

O crescimento da razão tecnocientífica e o surgimento do indivíduo atorsocial produziram uma catequese que parte da realidade do sujeito, possibilitando que este produza, por si, um conhecimento de Deus que o capacite a amadurecer na fé. Todavia, na sociedade contemporânea, dita como pós-moderna, marcada pelo pluralismo religioso, pela evolução dos meios de comunicação e por um sujeito que rejeita tanto o tradicionalismo, quanto o racionalismo que excluem suas emoções e sentimentos, percebe-se que os paradigmas catequéticos anteriores se tornaram insuficientes para comunicar a fé hoje.

Os desafios da contemporaneidade, marcada pelo processo crescente de descristianização, exigem a construção de um novo paradigma catequético. $O$ homem contemporâneo, inserido numa cultura pluriétnica e plurirreligiosa, já não aceita mais nem uma catequese doutrinária, que lhe imponha preceitos a ser cumpridos, tampouco uma catequese racionalista, que desconsidere seus sentimentos. $\mathrm{O}$ indivíduo dos tempos atuais deseja uma catequese que o reconheça como um todo, em sua materialidade, sentimentos e possibilidade de transcendência. Mais que doutrinação ou engajamento sociopolítico, o 
contemporâneo deseja um encontro com o Totalmente transcendente, com Deus, capaz de conceder sentido para sua vida e suas ações, obrigando à construção de novos caminhos catequéticos capazes de suprir tais demandas:

É preciso passar de uma catequese que mantém e consolida a fé que já existe para uma catequese que desperta o desejo e propõe a novidade radical do Evangelho, porque já não podemos mais agir como se a Boa-nova fosse conhecida e estivesse inscrita na memória cultural das pessoas. (VILLEPELET, 2006, p. 94).

Não são poucos os catequetas e catequistas do mundo inteiro que percebem o esgotamento do processo catequético frente às demandas do mundo contemporâneo7. São muitos os que insistem em pontuar esse esgotamento, mostrando a caducidade dos paradigmas vigentes. Observações da realidade apontam para o surgimento de um novo paradigma, ainda em construção, que busca, inspirado na tradição catequética da Igreja, propiciar aos catequizandos um encontro pessoal com o Deus de Jesus Cristo. Busca-se não mais uma catequese doutrinária (ao modo do primeiro paradigma - os catecismos de Trento), tampouco uma catequese antropológica (ao modo do segundo paradigma - a renovação catequética), mas uma catequese iniciática, que proponha a fé como preciosidade, como dom capaz de fazer viver, de dar força para a vida:

Hoje [...] [a] pastoral de transmissão vai se tornando cada vez mais difícil, quase impossível. E o melhor é que na Igreja tomemos consciência, quanto antes, de que este modo concreto de transmitir a fé não funcionará no futuro. Deixamos para trás a sociedade estática, tradicional e homogênea de outros tempos e entramos numa sociedade dinâmica e em continua evolução. As novas gerações já não vivem olhando para o passado, mas para o futuro, para o novo, o emergente. Os jovens não aprendem a viver recordando seus antepassados, mas alimentando-se das novas experiências que a cultura atual lhes oferece. [...] A transmissão da fé já não pode ser concebida como uma simples reprodução da identidade cristã dos antepassados; as novas gerações não aprenderão a ser cristãs imitando seus pais nem seus sacerdotes ou catequistas. Terão que descobrir a originalidade e a força salvadora de Jesus Cristo por outros caminhos; sua maneira de pensar, expressar ou celebrar a fé não poderá ser a de seus pais ou avós. (PAGOLA, 2015, p. 15).

O processo de transmissão, outrora tão fecundo, foi interrompido e os contemporâneos não assumem mais uma fé herdada de seus antepassados, transmitida por osmose, fechada em torno de doutrinas, ensinadas pelos ditos doutos nos diversos horizontes de reflexão da teologia, ou presa em torno de

\footnotetext{
7 Denis Villepelet, Emilio Alberich, Luc Aerens, André Fossion, Donaciano Martinez Alvarez, Saborido Cursach e tantos outros têm insistido nesse ponto.
} 
devocionismos populares, propagados por grande parte dos fiéis, carentes de uma verdadeira iniciação catequética que lhes propiciasse um encontro pessoal com o Ressuscitado. Urge a necessidade de se pensar um novo paradigma catequético, capaz de superar os atuais modelos de ação pastoral, que muito frutificaram em tempos passados, mas que quase nada dizem aos contemporâneos.

Para Emilio Alberich, a dificuldade da transmissão da fé cristã na atual sociedade, tão marcada pela crescente descristianização, faz pensar nas dificuldades encontradas pela Igreja nas suas origens, quando, imersa no paganismo, não podia contar com a difusão da fé de forma automática, mas exigia dos evangelizadores a arte de iniciar os candidatos à fé cristã no mistério pascal:

Os pastoralistas, ao falar de "Iniciação Cristã", de "catequese iniciática" e de "pedagogia de caráter iniciatório", se referem à Iniciação Cristã entendida como aquela ação integral que marcou as gerações cristãs dos primeiros séculos, imersos no paganismo, e que, segundo parece, tem muito a dizer à "nova" catequese e transmissão da fé em nossos "tempos atuais" de indiferença religiosa e cristã. (ALBERICH et al., 2004, p. 136) ${ }^{8}$.

A descristianização ou exculturação da fé9 obriga a catequese a retornar aos seus caminhos primeiros, a voltar às suas raízes, e redescobrir a pedagogia original da fé, aquele caminho catequético que se sustenta sobre as bases da iniciação e que leva ao encontro pessoal com Jesus Cristo. Esse ato catequético proporciona experimentar a fé cristã como preciosidade que dá sentido à existência de quem acolhe o Ressuscitado. A pedagogia da iniciação propõe bem mais que um aprendizado de doutrinas, normas morais e comportamento ético; ela suscita desejo de seguimento de Jesus Cristo, de adesão a ele, ao projeto de seu Reino, por meio da experiência do encontro amoroso com ele. Tal movimento passa, necessariamente, pela construção de um novo caminho catequético que conduza o catequizando ao mergulho no mistério pascal do Ressuscitado. Eis a teologia catequética do terceiro paradigma, formulada por Denis Villepelet.

\footnotetext{
8 Tradução nossa.

9 Processo de expulsão da fé cristã do centro da sociedade, onde a fé cristã se posicionava como parâmetro axiológico, para definir todas as atividades humanas, servindo de parâmetro explicativo para todo fenômeno natural, social e antropológico. Atualmente, na sociedade ocidental, os valores cristãos deixaram de ser referência para a vida humana. O cristianismo já não estrutura mais a vida do contemporâneo como fora outrora. Emergiu um novo modelo de sociedade, a-religiosa, sem vertentes cristãs. (CARMO, 2016, p. 170).
} 
Cada paradigma catequético possui um caminho pedagógico próprio, conforme os objetivos almejados. Sendo o objetivo do primeiro paradigma eliminar a ignorância religiosa por meio da transmissão da doutrina cristã católica, o caminho catequético viável se dava da fides quae creditur para a fides qua creditur $^{10}$. A insistência na doutrina (a fides quae) acontecia pelo desejo de levar o catequizando à obediência da fé (a fides qua) por meio da assimilação dos conteúdos ensinados. Tal caminho era condizente com os tempos de cristandade, em que a fé era transmitida pelos pais e pela sociedade. Bastava burilar a fé ensinando seus conteúdos mais fundamentais, suas orações, seus ritos. Nesse paradigma, vai-se da fides quae, entendida como doutrina ou depósito da fé, para a fides qua, entendida como a obediente, resposta do catequizando à fé que lhe fora transmitida.

Já no segundo paradigma, fruto da modernidade, delineou-se uma trajetória diversa dos tempos da cristandade, partindo da fides qua creditur para a fides quae creditur ${ }^{11}$. O foco já não se encontra mais sobre a doutrina e sobre o catequista que detém o saber da fé, mas sobre o catequizando e sua realidade existencial. Uma catequese marcadamente antropológica se impôs por força da modernidade que exigia dar as razões da fé. A fides qua creditur, entendida como o ponto de partida do ato catequético, não era mais a obediência da fé, mas a realidade concreta do catequizando que definia sua experiência de fé. A partir do catequizando, pretendeu-se chegar à fides quae creditur, não mais compreendida como doutrina ou verdade revelada de forma dedutiva, mas como mensagem de Deus, como fruto de uma hermenêutica realizada a partir da história.

A atual crescente descristianização da sociedade, porém, tem exigido a construção de um novo paradigma catequético, ainda em desenvolvimento. Seu caminho catequético vai da fides qua creditur para a fides qua creditur por

\footnotetext{
10 Caminho que parte da assimilação do conteúdo da fé (fides quae), ensinado pela comunidade eclesial, para a recepção e vivência do catequizando (fides qua), que assume valores e vive a partir do que a Igreja crê (fides quae). A Igreja transmite as verdades de fé (dogmas, doutrinas, ritos, orações, moral etc.) a serem assimiladas e vivenciadas pelos catequizandos.

11 Caminho que parte de uma fé infantil para uma vivência adulta da fé por meio da apropriação contextualizada das verdades de fé. Vai-se da fé do catequizando, experimentada na concretude de suas relações sociais e políticas e limitada por suas possibilidades cognitivas, para se chegar à verdade da fé, mensagem de Deus revelada no concreto da vida e que exige hermenêutica. "Os fiéis na sua vivência concreta da fé (a fides qua) interpretam sua história à luz da Palavra de Deus, pois a história humana e a história da salvação são uma só realidade. Essa Palavra é verdade, mas contextualizada num momento próprio da história onde a Igreja se encontra inserida” (CARMO, 2016, p. 239).
} 
meio da fides quae creditur ${ }^{12}$, conduzindo a um processo cíclico e contínuo de maturação da fé13. Nesse novo paradigma, a fides quae creditur é entendida não como um conjunto de verdades dogmáticas ou como mensagem a ser transmitida, mas como o próprio Mistério Pascal de Cristo. Já a fides qua é compreendida não como a obediência da fé a uma palavra imutável de Deus uma vez pronunciada, nem como uma construção laboriosa do catequizando a partir de sua realidade, mas como uma eterna iniciante, uma resposta contínua ao Deus que se revela aos que a ele se abrem. A fides qua não é nem ponto de chegada, nem ponto de partida do processo catequético, mas movimento contínuo de seguimento, despertando sempre novas indagações, impulsionando constantemente a um novo crescimento. Não se trata de um processo evolutivo retilíneo, mas um movimento cíclico espiral, com altos e baixos, avanços e retrocessos, necessitando sempre de uma nova reconstrução. O terceiro paradigma catequético não propõe apenas um novo caminho, mas um novo modo de compreensão da fides quae e da fides qua creditur, traçando uma nova proposta catequética a partir dos desafios emergentes a serem superados.

\section{FORMAÇÃO DO TERCEIRO PARADIGMA}

Um paradigma catequético é formado por diversos parâmetros dominantes de campos diferentes do conhecimento, que se interagem e caracterizam um modo próprio de pensar e fazer catequese. Os campos social, antropológico, eclesial, pedagógico e teológico fornecem parâmetros diferentes para cada paradigma catequético. O terceiro paradigma se sustenta sobre as bases de uma a) sociedade complexa (campo social); b) um indivíduo-sujeito (campo antropológico); c) uma Igreja templo do Espírito (campo eclesial); d) uma teologia pneumatoderivada (campo teológico), e e) uma pedagogia da iniciação (campo pedagógico):

\footnotetext{
12 Assim mesmo: Da fides qua para a fides qua pela mediação da fides quae. Pode parecer estranho à primeira vista o caminho sugerido pelo catequeta francês. Afinal, como sair da fides qua e ir para a fides qua? Para o pensamento cartesiano dos modernos, esse deslocamento não parece possível, mas não para os pós-modernos. Entendida a fides qua como a experiência cristã de Deus, Villepelet afirma que hoje o ato catequético vai da experiência cristã de Deus para a experiência cristã de Deus, mas não necessariamente uma experiência mais lúcida, mais esclarecida ou mais madura que a anterior; apenas uma experiência sempre necessitada de ser afirmada e partilhada na comunidade eclesial. Tal experiência é feita pela mediação da fides quae, entendida como o mistério pascal ou um banho eclesial de símbolos e significados.

13 Caminho contínuo que parte da experiência de fé do catequizando para sucessiva experiência de fé do mesmo, por meio do mergulho constante e cada vez mais profundo, no Mistério Pascal de Cristo. A fé cristã não é entendida como algo que se atinge, mas como constante devir ou vir a ser, não podendo ser alcançada sua plenitude maturativa. $\mathrm{O}$ caminho catequético não busca a maturidade cristã, mas o discipulado constante que brota da reiterada experiência do encontro com o Ressuscitado.
} 


\section{a) Sociedade Complexa}

As práticas catequéticas não são realidades abstratas, subjetivas, mas encontram-se inseridas dentro de uma realidade existencial concreta: a vida do homem e suas relações. Por isso, ao se falar em construção de um novo paradigma catequético, é necessário reconhecer a realidade existencial na qual ele acontece. A sociedade contemporânea apresenta-se, marcadamente, multirreferencial, diversificada. Nela, realidades heterogêneas, mutáveis, coexistem e se sustentam sem se excluírem. Elas "perseguem seus fins próprios muitas vezes antagônicos e, no entanto, permanecem inseparavelmente unidas" (VILLEPELET, 2007, p. 139). Em um primeiro olhar, pode parecer confuso, mas trata-se, na realidade, de um "caos organizado". Marca registrada da sociedade complexa é sua pluralidade, a diversidade de possibilidades que coexistem na abordagem de temas e situações. Uma mesma questão pode ser respondida de diversas formas. As explicações totalizadoras, unilaterais, são recebidas pelo pós-moderno com desconfiança; o diálogo, a troca, é condição essencial nesse tipo de sociedade.

\section{b) Indivíduo-sujeito}

A práxis catequética se direciona a pessoas reais, concretas, que vivem e interagem com as realidades que as circundam. É, portanto, fundamental conhecer o contemporâneo, destinatário e sujeito da catequese. Diferentemente do período da cristandade, em que o indivíduo se colocava como parceiro das instituições - especialmente da Igreja -, ou da modernidade, em que esse se apresentava como ator social, desejoso de mudar o mundo, o sujeito contemporâneo somente quer ser dono de si mesmo, sujeito da própria vida. "Neste atual momento histórico [...] a recomposição dos aspectos gira em torno do papel que se atribui ao sujeito individual. [...] Com isso experimentamos a desvalorização do outro lado da moeda: o tradicional e o institucional, a memória histórica, a pertença e a perenidade” (AMADO, 2010, p. 567). O referencial já não se encontra no Deus da cristandade, tampouco na razão moderna, mas dentro do próprio sujeito que busca construir sua identidade. Mais que o compromisso com a Igreja ou com a sociedade, o compromisso do homem atual é consigo mesmo, com suas demandas. Sua maior obrigação não se encontra nos laços de pertença, sejam eles eclesiológicos ou sociais. Encontra-se na sua liberdade, na sua interioridade, pois as referências externas tornaram-se múltiplas e não são mais capazes de lhe dar a direção a tomar. As 
referências externas, agora fragilizadas, migraram para dentro de cada indivíduo que procura se construir, que deseja ser sujeito de sua própria vida:

O homem pós-moderno vive sob o peso de si mesmo; carrega o fardo de sua cruz existencial, sem nenhum cirineu-social para ajudá-lo. Vê-se na obrigação de efetuar um árduo e demorado trabalho sobre si mesmo, sem manuais que indiquem por onde começar. Vive a fadiga de ser ele mesmo. (CARMO, 2016, p. 169).

Vivendo as fadigas próprias do processo de construção da própria identidade, o contemporâneo vai, ao longo de sua caminhada, construindo sua forma de ver, interpretar e valorar as realidades que o cercam. Para esse indivíduo-sujeito, a teologia teoderivada da cristandade diz pouco, pois é muito dedutiva, presa a verdades indiscutíveis, muitas vezes inacessíveis à razão. A teologia cristoderivada da modernidade, centrada na razão crítica, lhe parece muito militante, muito esclarecida, não lhe fala ao coração. Ela se sustenta numa utopia projetada para o futuro, sem referências nos desejos individuais. Resta pensar outra teologia capaz de falar ao coração dos contemporâneos.

\section{c) Teologia Pneumatoderivada}

O terceiro paradigma deseja construir suas bases sobre uma teologia mais pneumatoderivada. Por meio da ação do Espírito, o Filho se deixa experimentar no seu mistério pascal, revelando quem é o Pai: pura misericórdia ${ }^{14}$.

Nessa teologia, a fides quae creditur não é entendida como doutrina (primeiro paradigma) ou mensagem (segundo paradigma), mas como o próprio Mistério Pascal de Cristo, no qual o sujeito é convidado a mergulhar. O conhecimento de Deus não é nem a apreensão de uma doutrina, nem uma mensagem interpretada a partir da realidade; ele se dá na ação do Espírito que continua agindo em todo aquele que se abre para fazer a experiência do encontro com Jesus Cristo.

A catequese está centrada na "ação do Espírito Santo, dado por Jesus aos seus para que eles vivam em comunhão com o Pai. Na ação do Espírito, a realidade humana encarnada por Jesus de Nazaré continua sendo tocada pela graça do Pai” (CARMO, 2016, p. 173). O paradigma catequético da contemporaneidade pede uma teologia pneumatoderivada, que permita ao Espírito soprar onde quer e da maneira que lhe convier. Esse reconhecimento obriga a catequese a valorizar e acolher ações que não possuem, necessariamente, a Igreja como

14 Como afirma o Papa Francisco no título de sua obra: O nome de Deus é misericórdia. São Paulo: Paulus, 2016. 
sujeito ativo executor. Uma nova compreensão de Igreja se faz urgente, uma Igreja aberta, acolhedora, que se empenha no diálogo; uma Igreja que se demarca pela ação do Espírito e não por limites geográficos ou determinações do direito.

\section{d) Igreja, templo do Espírito}

Se a ação do Espírito está garantida dentro, mas também fora da Igreja, a verdade só pode ser encontrada na partilha, na troca e no diálogo. A Igreja, antes entendida como detentora da verdade (Corpo cuja cabeça é Cristo) ou como povo de fé militando em construção do Reino (Povo de Deus), nesse paradigma ela passa a se compreender como lugar propício para as relações, a partir do encontro pessoal com Cristo que o Espírito suscita (Igreja, templo do Espírito). Nela a comunidade se reúne com o seu Senhor, é por ele alimentada, movida por seu Espírito. Não se trata de pensar a eclesia sem organização ou hierarquia, mas de construir fraternidade mesmo nas assimetrias das relações, pois é o mesmo Espírito que age. Nesse paradigma, a Igreja é compreendida como espaço privilegiado para o encontro com o Ressuscitado e com os demais semelhantes, lugar de convivialidade, de partilha, de fazer e trocar experiências, de permitir-se tocar por Deus. Ficam minimizadas as demarcações espaciais, redutoras, ampliando-se os horizontes eclesiais. "As pessoas se sentem Igreja em qualquer espaço, em qualquer ajuntamento, em qualquer celebração onde o Espírito de Deus age" (CARMO, 2016, p. 175). Reconhecendo o protagonismo do Espírito de Deus, consequentemente, reconhece-se que sua ação não pode ser limitada por estruturas físicas, nem do direito, nem hierárquicas.

\section{e) Pedagogia da Iniciação}

Para que o catequizando possa fazer sua experiência de Deus em Jesus Cristo, é preciso que a catequese favoreça um caminho pedagógico capaz de propiciar o mergulho no mistério. Frente às demandas do sujeito contemporâneo, percebe-se que tanto a pedagogia do ensino (própria da cristandade) quanto a pedagogia da aprendizagem (própria da modernidade) são inapropriadas para a transmissão da fé nos dias atuais. A primeira caracteriza-se mais pela doutrinação, como se Deus fosse uma elaboração dogmática que cabe na cabeça ou uma verdade imutável à qual se deve assentir sem maiores questionamentos ou experiências pessoais que a ressignifiquem. A 
segunda corre o risco de eliminar o mistério, quando entende que o conhecimento de Deus é fruto da reflexão da realidade.

Uma catequese verdadeiramente iniciática possui em alta conta o mistério pascal de Cristo. Ela procura propiciar uma experiência pessoal de Deus e um mergulho no seu mistério. Sabe-se que Deus não é uma incógnita que se encontrada depois de longa investigação, nem mesmo um Deus que se identifique com as realidades humanas por mais que se mostre e se revele nelas. A pedagogia da iniciação sabe que Deus é o Totalmente Outro que se diz nas palavras e realidades humanas, mas está sempre a nos surpreender com seu amor e sua presença em nossa história. As necessidades atuais exigem uma catequese que não seja nem dedutiva (ao modo dos catecismos de Trento) tampouco indutiva (ao modo da renovação catequética), mas, ao mesmo tempo, dedutiva e indutiva, salvaguardando, concomitantemente, o mistério de Deus e a resposta livre e consciente do ser humano (CNBB, 2009, n. 40):

Quando se fala de iniciação, pensa-se em mergulho num banho de significações que a pessoa não pode inventar nem descobrir por ela mesma (VILLEPELET, 2008c, p. 7) ${ }^{15}$. Tendo experimentado esse mergulho no mistério, o iniciado decide se ele quer este estilo de vida para si ou não. Ele nutre a fé, saboreia a presença de Deus na qual a comunidade vive mergulhada, nutre-se do alimento da Palavra que é o pão cotidiano da comunidade crente. As explicações, as formulações necessárias que tentam dar razões da fé não foram esquecidas, mas o mergulho precede. (CARMO, 2016, p. 179).

Para que a catequese comunique a experiência cristã de Deus, mergulho no seu mistério capaz de conceder novo sentido à vida, é preciso transformar as comunidades em verdadeiros "espaços" favorecedores do encontro de liberdades, fomentando a partilha de experiências e a construção da identidade pelo reconhecimento da interioridade. As comunidades catequizadoras são desafiadas a se tornarem espaços de convivialidade, sem pressupostos que seus participantes tenham já uma fé herdada dos pais ou da comunidade. É preciso que as comunidades se tornem lugar de fraternidade, de partilha, de solidariedade, de autenticidade, fontes de iniciação na vivência e no testemunho dos mistérios de Deus.

A verdadeira iniciação cristã exige “provar”, saborear, experimentar. Trata-se de uma catequese mais orante e celebrativa, em que os símbolos, ritos e gestos são de fundamental importância. A experiência de Deus não se dá por um

\footnotetext{
${ }^{15}$ VILEPELET, Denis. Transmettre: initier, intérioriser e fraterniser. Les cahiers de l'Atelier, n. 517, 2008, p. 3-11.
} 
"curso", previamente destinado à recepção de algum sacramento, mas através do mergulho no seu mistério.

O primeiro passo de uma catequese iniciática é a experiência da presença de Deus, a relação de proximidade com ele, criando-se intimidade. Em seguida, busca-se o aprofundamento mistagógico do mistério experienciado não como forma de aquisição de conhecimento intelectual, mas como possibilidade de aprofundamento no mistério vivenciado para, cada vez, mais saboreá-lo. Uma pedagogia verdadeiramente iniciática utiliza-se das múltiplas formas de experiências humanas como possibilidade de estabelecer relação com Deus. As orações mais simples ou as reflexões mais complexas, as grandes contemplações como também os pequenos silêncios cotidianos, tudo é possibilidade de encontro com Deus, expressão da intimidade entre a criatura e o Criador, geradora de sentido para a vida e para a caminhada existencial dos indivíduos:

Com a sua novidade, Ele pode sempre renovar a nossa vida e a nossa comunidade, e a proposta cristã, ainda que atravesse períodos obscuros e fraquezas eclesiais, nunca envelhece. Jesus Cristo pode romper também os esquemas enfadonhos em que pretendemos aprisiona-lo, e surpreende-nos com sua constante criatividade divina. Sempre que procuramos voltar à fonte e recuperar o frescor original do Evangelho, despontam novas estradas, métodos criativos, outras formas de expressão, sinais mais eloquentes, palavras cheias de renovado significado para o mundo atual. $\mathrm{Na}$ realidade, toda a ação evangelizadora autêntica é sempre "nova". (EG, 11).

O terceiro paradigma propõe um retorno à pedagogia da iniciação, a "pedagogia original da fé", não como regresso nostálgico ao passado glorioso, mas como ruptura com esquemas enfadonhos e ultrapassados que pouco ou nada dizem ao contemporâneo. É preciso abrir espaços para que a criatividade divina refrigere os métodos de anúncio do evangelho, trazendo à tona a significância de Deus para o mundo contemporâneo. Faz-se urgente a transposição de uma pedagogia marcadamente intelectiva para uma pedagogia verdadeiramente iniciática, valorizando, antes que o conhecimento, a experiência pessoal do mistério de Deus na concretude da vida cotidiana.

\section{CONSIDERAÇÕES FINAIS}

Os paradigmas catequéticos são compostos por uma síntese de orientações que, a partir das necessidades emergentes em cada tempo, procuraram induzir a práxis catequética. Eles emergem quando as práticas catequéticas se apresentam insuficientes frentes às demandas insurgentes, sejam advindas de 
conflitos (como no caso da Reforma Protestante), sejam provindas da mudança de mentalidade (advento da modernidade e, posteriormente, da pósmodernidade). Implicitamente aos paradigmas, encontramos aquilo que é a opção pastoral fundamental de toda a Igreja: a evangelização. Não estamos dizendo que a evangelização se resume à catequese, mas que esta se apresenta como fundamental instrumento da ação evangelizadora.

Com o advento da Reforma Protestante surge o primeiro paradigma catequético: o paradigma da cristandade. Sentindo-se ameaçada pelo florescimento e crescimento das igrejas protestantes, especialmente a partir do conflito com Lutero, a Igreja católica viu-se impelida a construir um processo catequético que fosse capaz de afirmar e sobrepor sua identidade sobre as igrejas que emergiam da reforma. Surge, assim, uma catequese preocupada com a "doutrinação", focada sobre os catecismos, fonte da doutrina oficial da Igreja, e sobre os catequistas, que possuíam a incumbência de transmiti-los como conteúdo a ser inteligivelmente assimilado. Todavia, o advento da razão moderna e suas novas demandas impuseram a necessidade de elaboração de um novo paradigma mais condizente com a sua realidade contextual. Surge, assim, o segundo paradigma catequético.

O segundo paradigma catequético, ou paradigma da modernidade, surge com o advento de uma nova sociedade, moldada a partir das promessas da razão moderna. Frente às demandas de uma sociedade evolutiva, que olha para o futuro, de um indivíduo racional, que não mais aceita ser colocado como "mais um em meio à massa”, mas que deseja ser agente sociotransformador da sociedade e da história humana, a catequese doutrinária do primeiro paradigma mostra-se insuficiente. Surge, assim, um paradigma catequético enraizado na realidade existencial do sujeito, que parte da vida concreta para a apropriação do conteúdo da fé, a fim de se passar de uma fé infantil para uma fé adulta. Aqui, o foco já não se encontra nos catecismos e nos catequistas, mas na realidade vivida pelo catequizando, gerando diversos manuais catequéticos em conformidade com a pluralidade de contextos existenciais, e no catequizando, que não mais recebe passivamente "uma doutrinação", mas constrói, por si mesmo, a sua fé, baseado no princípio catequético da interação entre fé e vida.

Se nos atentarmos bem, perceberemos que estes dois paradigmas se encontram bem delineados: o primeiro como resposta às "ameaças" advindas da Reforma Protestante; o segundo surgido a partir da virada antropológica moderna. O paradigma da cristandade responde bem às demandas da Reforma Protestante, afirmando a identidade cristã-católica. O paradigma catequético da modernidade constrói uma catequese antropológica, capaz de responder às 
demandas da modernidade. Todavia, ambos se apresentam insuficientes frente às demandas do homem contemporâneo, mostrando-nos a urgente necessidade da construção de um novo paradigma. Surge assim, o terceiro paradigma catequético ou paradigma da pós-modernidade, ainda em construção.

O terceiro paradigma catequético traz, como grande esforço, pensar a catequese não como processo de assimilação intelectiva de conteúdos, seja pela pedagogia do ensino (paradigma da cristandade), seja pela pedagogia da aprendizagem (paradigma da modernidade), mas como lugar de encontro com o Ressuscitado, oportunidade de mergulho cada vez mais profundo no seu mistério, capaz de transformar as vidas e as ações das pessoas. Aqui a preocupação não é mais garantir a assimilação fidedigna do conteúdo doutrinal, mas propiciar uma experiência pessoal com Jesus Cristo, capaz de atingir e transformar a interioridade do sujeito. Trata-se de uma catequese iniciática, processo cíclico contínuo de maturação da fé, não para encher o intelecto, mas para mergulhar cada vez mais profundo no mistério pascal de Jesus Cristo.

O principal objetivo do terceiro paradigma é o retorno à "pedagogia original da fé”, pedagogia iniciática, da proposição, rompendo-se com esquemas que, ao longo do tempo, foram se mostrando ineficazes frente às exigências da sociedade e dos indivíduos. As mudanças de época não foram e não são desfavoráveis ao anúncio do Evangelho. É preciso que saibamos anunciar a boanova a partir das demandas que emergem dela, apresentando o evangelho com todo o seu frescor:

Voltar a Jesus e recuperar o frescor original do Evangelho significa voltar à única coisa que é fonte e origem da Igreja, a única coisa que justifica sua presença no mundo e na história. A única verdade da qual nos é permitido viver para caminhar criativamente para o futuro. (PAGOLA, 2015, p. 46).

Propor a construção de um novo paradigma catequético, capaz de suprir as necessidades dos tempos atuais a partir de Jesus Cristo e de seu mistério pascal, não se apresenta como tarefa fácil, mas extremamente necessária. A falência da catequese tradicional (paradigma da cristandade, consolidado em Trento) e da catequese moderna (paradigma da modernidade, consolidado com a renovação catequética) não nos permite mais permanecer estagnados. É preciso que busquemos respirar "novos ares". É necessário que construamos uma catequese capaz de apresentar a pessoa de Jesus, em toda a sua significância, para o homem contemporâneo. É essencial que o novo paradigma catequético (paradigma da pós-modernidade) continue em seu processo de implantação até que seja, finalmente, consolidado, realizando-se na práxis cotidiana de nossas 
catequeses. Reconhecemos que "o trabalho catequético é imenso, mas não sem esperança. [...] Embora tire sua energia do tesouro que a longa tradição catequética da Igreja representa, esse trabalho também deve inovar" (VILLEPELET, 2007, p. 119). Que o trabalho iniciado não fique estagnado, mas prossiga pelos pés corajosos daqueles que, apaixonados pela catequese, vislumbram novos horizontes.

\section{REFERÊNCIAS}

ALBERICH, Emilio; et al. Mesa Redonda. Catequética, v. 45, n. 3, p. 130-154, 2004.

AMADO, Joel Portella. Mudança de época e conversão pastoral: uma leitura das conclusões de Aparecida. Atualidade Teológica, v. 12, n. 30, p. 301-317, 2008.

Uma Igreja em mudança de época: pontos relevantes para a compreensão da Igreja na segunda década do século XXI. Revista Eclesiástica Brasileira, v. 70, n. 279, p. 565-579, 2010.

CARMO, Solange Maria do. Catequese no mundo atual: crise, desafios e um novo paradigma. São Paulo: Paulus, 2016.

CONFERENCIA NACIONAL DOS BISPOS DO BRASIL. Diretrizes Gerais da Ação Evangelizadora da Igreja no Brasil 2011-2015. São Paulo: Paulinas, 2011. (Documento 94).

Iniciação à vida cristã: um processo de inspiração catecumenal. São Paulo: Paulinas, 2009. (Estudos 97).

CONGREGAÇÃO PARA O CLERO. Diretório Geral para a Catequese. São Paulo: Paulinas, 1998.

[DGC 138. Diretório Geral Para a Catequese. Disponível em: < http://www.vatican.va/ roman_curia/congregations/cclergy/documents/rc_con_ccatheduc_doc_17041998_di rectory-for-catechesis_po.html>. Acesso em: 08 dez. 2016.]

FRANCISCO, Papa. Exortação Apostólica Evangelii Gaudium. São Paulo: Paulinas, 2013.

O nome de Deus é misericórdia. São Paulo: Paulus, 2016.

LIBANIO, João Batista. Eu creio, nós cremos: tratado da fé. 2. ed. São Paulo: Loyola, 2004.

MOLINARIO, Joel. Il testo nazionale per l'orientamento della catechesi in Francia.Catechesi. v. 76, n. 6, p. 26-39, 2006.

PAGOLA, José Antônio. Voltar a Jesus: para a renovação das paróquias e comunidades. Petrópolis: Vozes, 2015.

VILLEPELET, Denis. O futuro da catequese. São Paulo: Paulinas, 2007. 
Los desafios planteados a la catequesis francesa. Sinite, n. 141, p. 87-102, 2006.

Recebido em 09/o8/2016 Aprovado em 15/10/2016 